London

jane@janefeinmann.com

Cite this as: BMJ 2021;375:n2849 http://dx.doi.org/10.1136/bmj.n2849 Published: 30 November 2021
COVID-19

\section{What happened to our national emergency stockpiles?}

When the pandemic began, many nations' emergency stockpiles came into the spotlight-and were found wanting. Twenty months later, JaneFeinmann asks what happened, and if procurement has got any better

\section{Jane Feinmann freelance journalist}

In the first half of 2020, Europe, the US, and UK experienced a chronic shortage of personal protective equipment (PPE) and medical apparatus such as ventilators, leading to an overheated global market. Asian countries, in contrast, largely avoided the scramble thanks to their national stockpiles and better procurement strategies.

Set up in the wake of the severe acute respiratory syndrome epidemic in 2003 and sustained through the avian flu outbreak in 2008, several Asian countries either had rigorously maintained stocks and/or a plan in place to quickly organise local production, supply, and distribution of this equipment. Singapore had a stockpile of 16 million high grade (N95) respiratory masks before the pandemic began. ${ }^{1}$ Faced with a shortage, the South Korean government took control of mask production in early March 2020, ${ }^{2}$ while the Hong Kong government subsidised local production of more than 12 million masks per month at eight authorised production facilities. $^{3}$

The wide discrepancy between East and West prompts "legitimate questions regarding the management of strategic stockpiles," wrote the authors of an international survey of covid-19 crisis management conducted by consultancy firm EY in June 2020. ${ }^{4}$

Though a feature of government planning in the UK and US as well as much of Europe since the late 1990s, national stockpiles in the West have been subject to underfunding and miscalculations.

In France, the national stockpile of face masks fell from 1.7 billion in 2009 ( 1 billion surgical masks and 723 million $\mathrm{FFP} 2$ respiratory masks) to 150 million surgical masks at the start of the epidemic, EY reports. In the UK, the value of the Department of Health and Social Care's emergency stockpile increased in the years up to 2011 when pandemic preparedness was identified as a national priority for the NHS. ${ }^{5}$ It then fell from $£ 831 \mathrm{~m}$ in 2013 to $£ 506 \mathrm{~m}$ by March 2019-a reduction of $€ 325 \mathrm{~m}$ over six years.

But that wasn't the only problem.

\section{Failure to prepare}

Public Health England's Pandemic Influenza Framework focused, as the name suggests, on "antivirals, antibiotics, and consumables" on the assumption a future pandemic would be caused by flu. ${ }^{6}$ A report showing the full inventory of the stockpile, published in May 2020, found that it did not contain any gowns and that 20 million of 26 million respirators and nearly half the stock of surgical masks had passed their use-by dates, with some showing signs of deterioration. ${ }^{7}$ By April 2020, the UK's pandemic stockpile had just 3\% of the estimated daily requirement of gowns to manage covid-19, according to the UK National Audit Office. ${ }^{8}$

The US strategic national stockpile wasn't short of funding, maintained with an annual budget of they were found to consist of "millions of doses of smallpox vaccine alongside thousands of caches of nerve gas antidote" to protect against an expected bioterrorist attack, says Andrew Lakoff, professor of sociology at the University of Southern California and author of Unprepared (2017), which explores how the US responds to public health emergencies. ${ }^{9}$

The available PPE had been distributed to US states at the time of the $2009 \mathrm{H} 1 \mathrm{~N} 1$ epidemic and had never been replenished. A contract to replace thousands of ventilators used at the time of the $\mathrm{H} 1 \mathrm{~N} 1$ outbreak remained unfulfilled when the company with the contract was taken over. ${ }^{10}$

The US was ready, but not for the pandemic, Lakoff told The BMJ. The American stockpiles, he says, were "assembled in preparation for a particular imagined future and well prepared for a range of possible threats-but not covid."

And that problem continued. A year and a half after covid-19 first struck, the US Strategic National Stockpile was short "by hundreds of millions of surgical masks, gloves, and gowns, with an inventory that's less than $7 \%$ of federal targets," Politico reported in June 2021.

\section{Centralised planning}

The EU also struggled to develop a coordinated response in the early phases of the pandemic, amid shortages of essential medicines and equipment. ${ }^{11}$

Lombardy, northern Italy, which had the highest number of cases in the world at the time, was let down by the Italian health service's highly decentralised governance system, according to EY. Spain, which had a similarly decentralised system without a centralised procurement policy, also failed to anticipate the need for masks.

But by late March, the EU had established RescEU-a cross-border bulk buy order amounting to $€ 1$.5bn over seven years for kit, including 65 million medical masks, 280 million pairs of gloves, as well as goggles, $\$ 600 m$. But once stocks were accessed in early 2020 , 
face shields, surgical masks, gowns, and aprons. ${ }^{12}$ The items are planned as a "last resort to be called upon by an individual country in an emergency situation when its national capacities are no longer sufficient."

The contract for generating the medical stockpiles was awarded to Germany in the first year, and then to The Netherlands, Belgium, Slovenia, and Germany in 2021. As of February 2021, RescEU had delivered 1.3 million protective face masks and several hundred thousand pairs of gloves, gowns, and other supplies to member states, ${ }^{13}$ and the stockpile is intended to be in operation until December 2027. ${ }^{14}$

The UK had some successes in procurement. In September 2020, the UK National Audit Office (NAO) reported an increase in the number of ventilators from 9100 before the pandemic to 30 ooo by early August ${ }^{15}$ after a collaboration between the Department of Health and Social Care (DHSC) and the Cabinet Office. Meg Hillier, chair of the Public Accounts Committee, said at the time ${ }^{16}$ that it "sets a benchmark for procurement during the pandemic and shows that it's possible to work at pace and get results without writing a blank cheque-while keeping the chancers at arm's length.”

That said, the scramble for PPE during April and May 2020 has been widely criticised. At that point, NHS procurement became "highly visible due to the size of the spend, its largely centralised nature, and the political debates around healthcare in the UK," says Aris Georgopoulos, assistant professor in law at Nottingham University and co-lead on human rights and social sustainability at the Public Procurement Research Group.

The result was "an extremely overheated global market buying huge volumes of PPE often from suppliers that were new to the PPE market," according to the NAO report, ${ }^{8}$ with the UK spending on PPE increasing by a factor of 100 , from $€ 146 \mathrm{~m}$ in 2019 to £15bn for 2020/21. According to a list published 16 November, 47 firms won contracts via the UK government's fast track "VIP lanes," ${ }^{17}$ when deals were struck with ministers' close contacts, supposedly for expediency. ${ }^{18}$ Such allegations have also been levelled at public figures in the US. ${ }^{19}$

The UK supply included hundreds of millions of "potentially unsuitable" respirator masks and other PPE items, the NAO reported, with suggestions that parking them may have contributed to world trade problems. The port at Felixstowe almost ground to a halt in the second half of 2020 after 11 ooo shipping containers, filled with $\mathrm{PPE}^{20}$ intended for NHS doctors and nurses, were abandoned on the quayside for several months until they were finally moved in November 2020.

The debacle does seem to have led to improvements though.

The four governments of the UK worked with the NHS and its supply chains to centralise procurement of PPE in a "parallel supply chain," a mechanism that took several months to set up. From November 2020 , each government was required to have in place a new PPE strategy that provided a minimum of four-month stockpiles of face masks, visors, and gowns. These are guaranteed to be supplied free of charge to healthcare providers until March 2022-and a

consultation is currently under way to extend that for a further 12 months until March 2023 at a cost of £6oom. ${ }^{21}$

Efforts are also being made to increase the manufacturing of PPE domestically. "Pre-Covid, $100 \%$ of National Services Scotland's PPE sources were overseas," a spokesman for the Scottish government told The BMJ, "Now nearly half of all PPE used in Scotland is manufactured in Scotland."
These initiatives mirror the example of Asian countries. South Korea, for instance, had "an arsenal of laws to fight possible epidemics," while the Taiwanese government "mobilised the army for line production of masks and nationalised postal services to distribute them," reported EY.

Now NHS procurement is "faced with a decision on whether to continue unquestioningly, adapt, or abandon its approach of outsourcing manufacture to China and other countries," says Georgopoulos, who contributed a chapter on the subject in Public Procurement Regulation inaCrisis: Global Lessons from the Covid 19 Pandemic (Bloomsbury 2021).

It could be that "the NHS will move to some localised and decentralised manufacture that's sustainable and competitive" he says.

Meanwhile, NHS Digital is developing an online procurement pipeline launched by the DHSC in August 2019. "22 "Such a platform could create a wider network in the supply chain with more small and local suppliers on the NHS radar if a surge in demand strikes," says Georgopoulos.

Most importantly, he says, the NHS could follow the example of RescEU by “creating networks among buyer organisations to make it possible to redistribute surplus stockpiles.” That could be networks of hospital trusts or UK countries. Potentially, the UK could even join RescEU as a “candidate country," according to some experts. $^{23}$

\section{Taking stock}

Today stockpiles of vaccines and anti-covid medications overshadow the continuing need for PPE and equipment in our emergency stockpiles.

A recent intervention by former health secretary Matt Hancock ${ }^{24}$ calling for mandatory vaccination for health workers before winter made no mention of ensuring adequate supplies of PPE for the NHS workforce this year. And incumbent health secretary Sajid Javid announced the stockpiling of two antiviral drugs that at the time had yet to be approved by the MHRA ${ }^{25}$ (Molnupiravir has since been approved). This comprises 480 ooo courses of molnupiravir and 250 ooo courses of ritonavir. Exact costs, particularly for ritonavir, are not yet known, but as a comparison the US is paying around $\$ 700$ per 5 day course of molnupiravir (or $\$ 1.2 b n$ for 1.7 million courses). ${ }^{26}$

With far fewer ventilators required than was anticipated, the UK now has a stockpile for future peaks in clinical need, NAO head Gareth Davies said at an event in September. The BMJ asked the DHSC to comment on the future of national stockpiles of PPE, but has yet to receive a response.

It's unknown how much stock RescEU currently has. The BMJ contacted Berlin based humanitarian charity Johanniter-Unfall-Hilfe, which helps coordinate the stockpile, but has yet to receive a reply.

In the US, on his first day in office in November 2020, President Joe Biden pledged to respond to shortfalls in PPE as well as vaccination and testing supplies. ${ }^{27}$ Yet it's vaccinations, and now anti-covid drugs, that hog the headlines.

A review of the country's Public Health Emergency Medical Countermeasures Enterprise in November 2021 warned that the emphasis was now on vaccines and diagnostics "that can be useful in public health emergencies, but the end game is about how we get that distributed." 28 It said further work is urgently needed "on 
the security of the supply chain and the efficacy of the last mile distribution process."

As the pandemic enters its third year, with supply chain issues continuing to be a cause for concern, this is a message that needs to be heard.

Competing interests: none.

Commissioned, not externally peer reviewed

116 million N95 masks available in national stockpile as haze covers Singapore. CNA 19 September 2019. https://www.channelnewsasia.com/singapore/haze-n95-face-masks-available-nationalstockpile-moh-government-1316276

2 Kim ET. How South Korea solved its face mask shortage. New York Times 1 April 2020. https://www.nytimes.com/2020/04/01/opinion/covid-face-mask-shortage.html

3 Wong B. New Hong Kong production group aims to give government 150,000 masks a week for battle against coronavirus epidemic. South China Morning Post 27 February 2020. https:/www.scmp.com/news/hong-kong/health-environment/article/3052753/new-hong-kongproduction-group-aims-give

4 International benchmark survey of COVID-19 crisis management. EY 2020. https://assets.ey.com/content/dam/ey-sites/ey-com/fr_fr/topics/health/ey-international-benchmark-crisis management-en.pdf

5 Davies H, Pegg D, Lawrence F. Revealed: value of UK pandemic stockpile fell by $40 \%$ in six years. Guardian 12 April 2020. https://www.theguardian.com/world/2020/apr/12/revealed-value-ofuk-pandemic-stockpile-fell-by-40-in-six-years

6 Public Health England. Pandemic influenza strategic framework. 2014. https://assets.publishing.service.gov.uk/government/uploads/system/uploads/attachment_data/file/344696/PI_Strategic_Framework_13_Aug.pdf

7 Howker E, Rabkin J, Basnett G, Pett H. Revealed: PPE stockpile was out-of-date when coronavirus hit UK. Channel 4 News 7 May 2020. https://www.channel4.com/news/revealed-ppe-stockpilewas-out-of-date-when-coronavirus-hit-uk

8 National Audit Office. The supply of personal protective equipment (PPE) during the COVID-19 pandemic. 2020. https://www.nao.org.uk/wp-content/uploads/2020/11/The-supply-of-personalprotective-equipment-PPE-during-the-COVID-19-pandemic-Summary.pdf

9 Illing S. Why the national stockpile wasn't prepared for this pandemic. Vox 15 April 2020. https://www.vox.com/2020/4/15/21210210/coronavirus-covid-19-national-strategic-stockpile

10 Palmer D. US medical stockpile wasn't built to handle current crisis, former director says. Politico 8 April 2020 www.politico.com/news/2020/04/08/national-stockpile-coronavirus-crisis-175619

11 Anderson M, Forman R, Mossialos E. Navigating the role of the EU Health Emergency Preparedness and Response Authority (HERA) in Europe and beyond. Lancet Reg Health Eur 2021;9:100203. doi: 10.1016/j.lanepe.2021.100203 pmid: 34661186

12 European Commission. COVID-19: Commission creates first ever rescEU stockpile of medical equipment. 2020. https:/ec.europa.eu/commission/presscorner/detail/en/ip_20_476

13 European Commission. Crisis management and solidarity. https://ec.europa.eu/info/live-worktravel-eu/coronavirus-response/crisis-management-and-solidarity_en.

14 Johanniter International. Update on rescEU medical stockpile. https://johanniter.org/3629/updateon-resceu-medical-stockpile/

15 National Audit Office. Investigation into how government increased the number of ventilators available to the NHS in response to COVID-19. 2020. https:/www.nao.org.uk/wp-content/uploads/2020/09/Investigation-into-how-the-Government-increased-the-number-of-ventilators.pdf

16 Roberts M. Coronavirus: NHS well stocked for ventilators this winter. BBC 30 September 2020 https://www.bbc.co.uk/news/health-54323566

17 lacobucci G. Covid-19: One in five government contracts had signs of possible corruption, report finds. BMJ 2021;373:n1072. doi: 10.1136/bmj.n1072 pmid: 33893123

18 Casalicchio E. Ex-Conservative chair helped multiple firms get UK PPE contracts. Politico (Pavia) 2021. https://www.politico.eu/article/conservative-uk-ppe-contracts-feldman-audit/.

19 Feuer W. House panel opens probe of White House trade advisor Navarro after abrupt cancellation of ventilator contract. CNBC1September 2020. https://www.cnbc.com/2020/08/31/coronavirushouse-panel-opens-probe-of-white-house-trade-advisor-navarro-after-cancellation-of-ventilatorcontract.html

20 Sullivan 0, Williams A, Geater P. Huge stockpile equivalent to 11,000 containers of PPE builds at Port of Felixstowe. East Anglian Daily Times 13 November 2020. https://www.eadt.co.uk/news/coronavirus-ppe-stockpile-fuels-felixstowe-delays-6549934

21 Department of Health and Social Care. Closed consultation. Extending free PPE to the health and care sector. 2021. https://www.gov.uk/government/consultations/extending-free-ppe-to-thehealth-and-care-sector/extending-free-ppe-to-the-health-and-care-sector

22 Trendall S. Government to roll out $\mathrm{f5m}$ pan-NHS procurement platform over next three years. Public Technology.net. 2019

https//hww.pubidednologynet/artides/news/govermment-roll-out-f5m-pan-nhs-proarement-platform-over-next-threeyears

23 Written evidence submitted by Dr Andrew Glencross (FRE0039). 2020. https://committees.parliament.uk/writtenevidence/7462/pdf/
24 Grierson J. NHS England staff should have Covid vaccine before winter. Hancock says. Guardian 8 Nov 2021. https://www.theguardian.com/world/2021/nov/08/nhs-england-staff-covid-vaccinewinter-hancock-health-mandatory

25 Mahase E. Covid-19: UK stockpiles two unapproved antiviral drugs for treatment at home. BM 2021;375:n2602. doi: 10.1136/bmj.n2602 pmid: 34697079

26 Willyard C. How antiviral pill molnupiravir shot ahead in the COVID drug hunt. Nature 2021. https://www.nature.com/articles/d41586-021-02783-1. doi: 10.1038/d41586-021-02783-1 pmid: 34625735

27 National strategy for the covid-19 response and pandemic preparedness. 2021. https://www.whitehouse.gov/wp-content/uploads/2021/01/National-Strategy-for-the-COVID-19 Response-and-Pandemic-Preparedness.pdf

28 Frieden J. How can the US avoid another COVID-19 stockpile disaster? Medpage Today 4 November 2021. https://www.medpagetoday.com/publichealthpolicy/publichealth/95450 